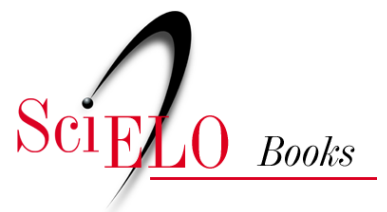

EDUFU

\title{
Promoção, operacionalização e funcionalidade do texto acadêmico
}

\author{
Sulemi Fabiano-Campo \\ José Antônio Vieira
}

\section{SciELO Books / SciELO Livros / SciELO Libros}

FABIANO-CAMPO, S., and VIEIRA, J.A. Promoção, operacionalização e funcionalidade do texto acadêmico. In: AGUSTINI, C., and ERNESTO, B., eds. Incursões na escrita acadêmicouniversitária: letramento, discurso, enunciação [online]. Uberlândia: EDUFU, 2017, pp. 35-53. ISBN: 978-65-86084-26-9. https://doi.org/10.7476/9786586084269.0003.

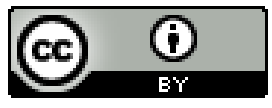

All the contents of this work, except where otherwise noted, is licensed under a Creative Commons Attribution 4.0 International license.

Todo o conteúdo deste trabalho, exceto quando houver ressalva, é publicado sob a licença Creative Commons Atribição 4.0. 


\section{Promoção, operacionalização e funcionalidade do texto acadêmico}

Sulemi Fabiano-Campo

José Antônio Vieira

A escrita de uma monografia é, em certa medida, exemplo de desenvolvimento de ciência na graduação. A produção universitária sofre grande influência e transformações em consequência da pressão de agências de fomento e amparo às pesquisas estaduais e nacionais, mas é interessante reconhecermos que, considerando os conceitos históricos sobre a produção científica, podemos, de certa maneira, questionar alguns parâmetros das produções desenvolvidas na academia.

A monografia é um dos primeiros passos do aluno em relação à produção acadêmica e contato com uma fundamentação teórica. Parte daqueles que escrevem um texto monográfico tem, nesse momento, sua primeira experiência significativa de escrita científica. É uma situação de pressão e cobranças para atender aos procedimentos estabelecidos por uma metodologia baseada na articulação de perspectivas teóricas e análises de dados que permitirão a realização da investigação proposta.

Nesta investigação, respondemos ao seguinte questionamento: Quais os efeitos de sentido produzidos a partir do modo de utilização da voz do outro na escrita de textos acadêmicos? 0 objetivo geral é analisar de que forma uma teoria é utilizada por um aluno de graduação na escrita do texto monográfico. Já os objetivos específicos são: 1) analisar 
as marcações do outro (autor, conceito teórico, área de conhecimento) na escrita acadêmica; e 2) observar os efeitos de sentido produzidos por essa marcação. Para a realização desta pesquisa, selecionamos duas monografias defendidas recentemente, por alunos do curso de Letras de uma universidade pública do País.

Foram fundamentais para o desenvolvimento da pesquisa os conceitos de heterogeneidade enunciativa de Authier-Revuz (2004), que nos possibilitou analisar as marcações do outro na escrita monográfica; e de valor de troca e valor de uso de Rossi-Landi (1985) que, ao considerar a linguagem como trabalho linguístico, permitiu-nos observar as diferenças de uso e a funcionalidade social de uma teoria na escrita acadêmica.

Ao analisar o modo de utilização do discurso de outros autores na produção escrita de monografias, foi possível perceber os seguintes aspectos: 1) a existência de diferentes formas de se caracterizar a produção escrita de textos acadêmicos evidencia as relações entre o que se escreve e o que já foi produzido; 2) a escrita baseada na repetição de conceitos já desenvolvidos contribui com a produção de efeitos de sentido que podem questionar a funcionalidade da produção acadêmica; 3) a marcação do discurso de outro autor pode desenvolver um efeito de sentido que cria a ideia de que o texto produzido possui a função de promover um autor ou um conceito teórico; e 4) a construção do sentido de promoção pode garantir a inserção do trabalho numa comunidade ou grupo científico em detrimento da produção escrita que articula a teoria em análise de dados.

Essas situações apontam para a existência de um texto acadêmico que circula a fim de promover a fundamentação teórica, que normalmente se configura como argumentação e sustentação da produção científica. Assim, as marcações do outro na escrita acadêmica destacam afirmações alheias em detrimento do dizer do pesquisador.

\section{Do teórico-metodológico}

Nossa principal fundamentação teórica é a Análise do Discurso de linha francesa que apresenta os conceitos relacionados à heterogeneidade enunciativa do discurso. Fazemos uso de conceitos da sociologia e da filosofia ao nos remetermos, na análise dos dados, às noções de valores de uso e de troca tomadas do marxismo. 
Para o desenvolvimento desta investigação, apoiamo-nos em AuthierRevuz (2004), por defender, em seus estudos, que todo texto conta com a participação de outros discursos, isto é, a presença de dizeres diferentes daquele para quem o locutor constrói o enunciado. A pesquisadora denomina tal fato de heterogeneidade constitutiva do discurso, que pode ser mostrada, marcada ou não marcada. Isso nos permite analisar as produções escritas, neste caso, as monografias que selecionamos como corpus deste trabalho.

Ao tratarmos das diferenças do texto com funcionalidade social, fundamentamo-nos na perspectiva da linguagem como trabalho linguajeiro, conceito desenvolvido por Rossi-Landi (1985), que toma a linguagem como trabalho linguístico e mostra como são estabelecidos os valores funcionais e sociais de um discurso produzido.

Temos como hipótese do trabalho que a produção escrita desenvolva dois valores, o de uso e o de troca, estabelecendo uma relação dialógica entre aquele que é citado e aquele para quem o texto é escrito. Para desenvolver esses dois valores, precisamos encontrar, em sua estrutura, uma mobilização da voz do outro que funcione como fundamentação de um dizer próprio e demonstre operacionalidade dos conceitos teóricos em análise dos dados.

Baseamo-nos em estudos sobre as concepções de escrita de Coracini (2010) e Ciência de Kuhn (2011). A primeira apresenta a perspectiva de implicação daquele que escreve na produção que desenvolve, isto é, uma inscrição de si no texto que produz; e a segunda apresenta as revoluções científicas como realizações universais, fornecedoras de problemas e soluções para todo praticante de ciência, e define a ciência normal como toda ciência vigente nos períodos desprovidos de uma revolução científica.

Elencamos a teoria da heterogeneidade enunciativa de AuthierRevuz (2004) como ferramenta de análise, a fim de observar a organização e a composição da escrita acadêmica, no que diz respeito à marcação e à participação de outros dizeres no discurso, com o intuito de identificar os efeitos de sentidos gerados em razão dos modos de escrita de um texto acadêmico, visto que os sentidos da escrita podem se diferenciar, em razão da forma como relacionamos o discurso produzido àqueles que o atravessam. Como recurso de análise, observamos como os conectores e os diversos conceitos teóricos na escrita do texto acadêmico podem demonstrar a articulação entre a reflexão teórica, a metodologia do trabalho e a análise de dados. 


\section{Dos dados que analisamos}

Selecionamos duas monografias de autores e anos de defesa distintos. A escolha deu-se em razão de os alunos possuírem perfis diferentes: um deles, reconhecido como um "bom" aluno, realizou os estudos sem nenhuma reprovação e passou pela experiência de ser bolsista de iniciação científica durante a formação; o outro se formou com reprovações em seu histórico e sem a experiência de iniciação científica antes da produção do trabalho monográfico.

Os dados que recortamos das duas monografias analisadas foram retirados de partes do texto, nas quais se espera uma articulação da teoria apresentada com a análise de dados. E, justamente por não percebermos essa relação entre teoria e análise, recortamos esses dados. Outro critério utilizado para selecionar o corpus foi a observação de trechos da monografia em que havia muita repetição de um autor ou a identificação de uma quantidade excessiva de conceitos descritos em poucas linhas de texto.

\section{Monografia 001 (Aluno A)}

O aluno A concluiu sua graduação no primeiro semestre letivo de 2009, cumprindo o curso em dez semestres (dois semestres a mais que o tempo mínimo de formação do curso de Letras). Foi aluno do mestrado da mesma universidade onde se formou. 0 seu trabalho fundamenta-se na teoria da Análise do Discurso de linha francesa e tem como título "Dança do Chorado: efeitos de uma memória".

Os objetivos do trabalho não estão explícitos, são apenas compreendidos a partir da leitura do texto, como: "analisar a transcrição de um depoimento relatado sobre a Dança do Chorado realizado por um morador da cidade de Vila Bela da Santíssima Trindade em Mato Grosso, com o intuito de observar as condições de significação do sujeito do Chorado no século XVIII", investigar "os modos como os sentidos se constituem e se institucionalizam no Chorado da atualidade" e, por fim, "compreender como se constitui o efeito metafórico do Chorado do século XVIII para o Chorado da atualidade".

A monografia tem 37 páginas, divididas em: resumo; introdução; capítulo um, dedicado às considerações teóricas; capítulo dois, dedicado à descrição do corpus; capítulo três, dedicado à análise; considerações 
finais; e referências bibliográficas. 0 corpus do trabalho é a gravação de um depoimento concedido ${ }^{1}$ sobre a Dança do Chorado ${ }^{2}$. As palavras-chave do trabalho acadêmico são: memória discursiva, resistência, subjetividade, silêncio e deslizes dos sentidos. Na introdução do texto, apresentam-se o objetivo e os autores utilizados como fundamentação da pesquisa, sem justificação ou demonstração da relevância do trabalho realizado.

O primeiro capítulo da monografia é nomeado como "Considerações teóricas", presta-se à apresentação das teorias e conceitos teóricos que o aluno indica como fundamentação para o trabalho. 0 segundo capítulo intitula-se "Configuração do corpus" e faz a descrição e apresentação do corpusque o aluno pretendia analisar. Ao final do trabalho, temos um capítulo dedicado à análise de dados nomeado com o mesmo título da monografia.

\section{Monografia 002 (Aluno B)}

O aluno B concluiu sua graduação no segundo semestre letivo de 2011, em oito semestres, completando a formação no prazo mínimo estabelecido. 0 seu trabalho também utiliza como fundamentação teórica a Análise do Discurso de linha francesa e leva o título "Jornal e poesia: o Alencar espelhado no discurso da língua". Apresenta-se como objetivo: "investigar as práticas discursivas no espaço de dizeres dos jornais O Povo (1879) e A Opinião (1878)", para “verificar a constituição da subjetividade no espaço discursivo do jornal e da literatura, que circulou em Mato Grosso na segunda metade do século XIX". O trabalho é fruto da participação em um projeto de pesquisa com fomento e o corpus foi recortado do material coletado para o projeto de pesquisa coletivo. Também foi publicado em uma revista acadêmica de circulação regional.

0 trabalho não tem pergunta de pesquisa e possuiu 55 páginas, divididas em: resumo; abstract; apresentação; um capítulo dedicado à fundamentação teórica, nomeado "Primeiras (In)junções teóricas”; um capítulo dedicado à análise dos dados, intitulado "Outros no mesmo: por um funcionamento literário-discursivo no jornal"; um capítulo de considerações finais, que é chamado de "Palavras (quase) finais"; bibliografia e anexos.

\footnotetext{
${ }^{1}$ Consideramos como depoimento relatado, porque a transcrição foi feita a partir de entrevista. $\mathrm{O}$ aluno solicitou a um morador da comunidade que desse seu depoimento sobre a dança do Chorado.

${ }^{2}$ Dança típica de comunidades quilombolas, nesse caso, do grupo que viveu na região da cidade de Vila Bela da Santíssima Trindade, MT.
} 
Os efeitos de sentido no texto acadêmico: promoção, operacionalização e funcionalidade

No dicionário Aurélio, encontramos as seguintes acepções do termo promoção: do latim promotione, "ato ou efeito de promover. Elevação ou acesso a cargo ou categoria superior; ascensão"; do inglês promotion, "O conjunto de atividades que visam fortalecer a imagem de uma marca, instituição, indivíduo, etc., [...]" (Ferreira, 1999, p.1.648).

As acepções dicionarizadas da palavra "promoção" funcionam como um ponto de referência para conceituarmos o que estamos chamando de efeito de promoção. Compreendemos que a escrita pode, de acordo com sua organização, denotar a imagem de que a função do texto produzido possui a funcionalidade de promover o conceito ou o autor utilizado como fundamentação teórica do trabalho. Tal situação nos permite dizer que é possível construir uma imagem cujo autor ou o conceito citado pertencem a uma categoria superior em relação a quem escreve o trabalho que analisamos.

Há um ponto em comum entre o que consideramos como efeito de promoção de um autor ou conceito e o significado da palavra promoção apresentada pelo dicionário. A ideia de "ato de promover" é a essência de nossa conceituação do termo: característica do trabalho acadêmico inserido em uma comunidade científica pela exaltação e reprodução de outro, cuja escrita não se desloca do já dito e se limita a repetir ou a utilizar uma teoria, um autor ou um conceito teórico como propaganda, sem delegar-lhes "utilidade".

O efeito de sentido de promoção pode se desenvolver de várias maneiras. Neste trabalho, tratamos sobre os atos de promover um autor e um conceito teórico. 0 primeiro é caracterizado, a partir da marcação e estruturação da escrita, pelo uso de excessivas citações de um mesmo autor sem estabelecer relação com o discurso produzido ou articulação com a proposta de investigação. A escrita que se utiliza de várias citações para reproduzir o discurso de um autor específico constrói um sentido pelo qual o texto coloca em evidência o autor citado, ao invés das palavras de quem escreve. 0 segundo, a promoção de um conceito teórico, limitase ao emprego de um ou vários conceitos sem necessariamente conhecer suas condições de produção, sem explicar ou articulá-los com os dados que compõem a pesquisa. 
Uma escrita repetidora, que origina o efeito de promoção de um autor ou de um conceito teórico, não desenvolve, em sua estrutura, uma operacionalização deles para contextualizar sua investigação. Por essa razão, compreendemos que existe uma relação entre a falta de articulação e mobilização da fundamentação teórica utilizada na proposta de pesquisa e a produção escrita baseada na reprodução.

Sustentamos que tal utilização de uma teoria funciona como um modo de garantir a inserção e aceitação de um texto acadêmico em uma comunidade científica, mesmo que os conceitos teóricos não estejam operacionalizados (utilizados em análise de dados ou na metodologia, por exemplo) ou não tenham funcionalidade no trabalho em que são empregados. Além disso, dependendo da forma como são desenvolvidas as marcações do outro na escrita acadêmica, dar-se-á destaque àquilo que é citado do outro em detrimento do dizer do pesquisador.

Partindo dos conceitos de trabalho linguístico de Rossi-Landi (1985), tratamos sobre a funcionalidade social da produção escrita realizada. Remetemos à representação e à relevância da produção na sociedade, ou seja, como uma nova produção exerce função social na comunidade, contribuindo com o desenvolvimento dela, respondendo a questionamentos e desenvolvendo novos conhecimentos. Se a escrita não se desloca, dificilmente poderá contribuir de forma produtiva para a sociedade, pois ela funciona como mecanismo de exaltação do que já foi produzido.

Esclarecemos que a modalidade de escrita que promove autor ou conceitos se diferencia daquela que tem como objetivo a divulgação científica, considerando que uma se estrutura na repetição do já dito e a outra contribui com o desenvolvimento do conhecimento sobre a ciência, através de um aprofundamento sobre um tema com propósito de disseminar, vulgarizar e difundi-lo.

\section{Os efeitos de sentido da escrita de monografias: a promoção de um autor}

Ao começar a análise, chamou-nos a atenção a recorrência de citações de um mesmo autor na seção dedicada à resenha teórica. 0 capítulo de considerações teóricas é composto de oito páginas e 44 parágrafos. Nestes, verificamos 25 marcações explícitas da voz de outro autor, das quais 22 indicam uma autora reconhecida na academia. Observamos que, 
no capítulo dedicado para análise, há 14 citações em discurso direto, introduzidas por conectores que evidenciam uma tentativa de adequação ou concordância com o discurso citado, e 24 tentativas de reformulações parafrásticas ${ }^{3}$ de conceitos teóricos que, em sua maioria, foram apresentados nas citações diretas de Orlandi.

Analisamos a escrita do aluno por meio de excertos que continham as formulações do autor que tão recorrentemente é citado, assim, focamo-nos numa análise dos conectores empregados na seção dedicada à exposição da teoria que embasa a monografia. Essa recorrência é significativa e cria a imagem de que o texto tende a utilizar apenas um autor para fundamentar o discurso produzido no trabalho. Juntamente com essa situação, temos uma inversão do papel de quem escreve com aquele que é citado, o que desenvolve o efeito de sentido de promoção de um autor, por meio da construção de um discurso consolidado pela repetição de outro autor.

Reconhecemos que as condições de produção ${ }^{4}$ podem influenciar no trabalho realizado, porém analisamos como é constituída uma escrita que desenvolve um efeito de sentido de promoção, para, ao final do trabalho, discutir sobre a formação escrita e refletir sobre os processos que contribuem e influenciam os modos de utilização de teorias em uma produção acadêmica.

0 recorte transcrito a seguir foi retirado da primeira monografia que analisamos. Classificamo-lo como Excerto 1, do aluno A. 0 trecho que analisamos está no início do capítulo dedicado à análise. Tratase da apresentação de uma citação recuada que traz uma explicação sobre a diferença dos estudos da Análise do Discurso e dos conceitos de transmissão da Teoria da Comunicação. Selecionamos esse excerto para mostrarmos como aquele que escreve inicia o capítulo dedicado à análise de dados de sua investigação sem mencionar o objeto ou mesmo apresentar o capítulo de análise, seus objetivos e a proposta daquela parte do trabalho. 0 conceito utilizado como fundamentação do trabalho também não é apresentado.

\footnotetext{
${ }^{3}$ Conceito apresentado por Fuchs (1985), que explica as tentativas de se dizer sobre um mesmo assunto por meio de diferentes construções sintáticas.

${ }^{4}$ Segundo Possenti (1997, p.369), para a Análise do Discurso, o conceito de condições de produção exclui definitivamente um caráter "psicossociológico", mesmo na "situação concreta". Os contextos imediatos somente interessam na medida em que, mesmo neles, funcionam condições históricas de produção, ou seja, os contextos fazem parte de uma história
} 
Anteriormente ao dado que recortamos, há um capítulo dedicado à transcrição do depoimento relatado de um morador da comunidade quilombola de Vila Bela, nomeado como Sr. Elísio.

\title{
Excerto 01 - Aluno A
}

\begin{abstract}
Conforme Orlandi (2002:21), não podemos considerar o depoimento relatado apenas como um código, ou mero meio de transmitir informações.

Para a Análise de Discurso, não se trata apenas de transmissão de informação, nem há essa linearidade na disposição dos elementos da comunicação, como se a mensagem resultasse de um processo assim serializado: alguém fala, refere alguma coisa, baseando-se em um código, e o receptor capta a mensagem, decodificando-a. $\mathrm{Na}$ realidade a língua não é só um código entre outros, não há essa separação entre emissor e receptor, nem tampouco eles atuam numa sequência em que primeiro um fala e depois o outro decodifica etc. Eles estão realizando ao mesmo tempo o processo de significação e não estão separados de forma estanque. Além disso, ao invés de mensagem, o que propomos é justamente pensar aí o discurso.

Como já discutimos sobre a noção de leitura (Orlandi, 2004), no relato, por se tratar de um material simbólico, não podemos, na perspectiva da A. D, visar compreender o que esse texto está querendo dizer, mas compreender como o discurso faz significar determinados efeitos de sentidos e como esses efeitos de sentidos se significam e funcionam. Em relação às discussões de Orlandi $(2002,2004)$, compreendemos o relato como o espaço simbólico do discurso sobre a Dança do chorado. Neste material simbólico de análise, os sentidos que se significam e que funciona fazem a partir de um imaginário de unidade e de autoria. De acordo com Orlandi (2001:65), o imaginário de unidade de sentidos produz a textualidade e o discurso imaginário da função-autor.

Falando da função-autor tenho dito o que ela constrói uma relação organizada - em termos de discurso - produzindo um efeito imaginário de unidade (com começo, meio, progressão, não contradição e fim). E a isto chamo de textualidade. Toda vez que tenho isso, tenho a função autor, colocando imaginariamente o sujeito na origem do sentido e sendo responsabilizado pela produção.

Interessante ressaltar que esse imaginário de textualidade ocorre pelo gesto de interpretação. É o gesto de interpretação que possibilitará a materialização do simbólico pelo discurso. No depoimento sobre o Chorado, esse imaginário de unidade dos sentidos pode ser compreendido ao tratar de maneira sequencial o primeiro, o segundo e o terceiro momento da Dança do Chorado. (p.20-21).
\end{abstract}

Na linha 01 , há o uso do conector "conforme", que marca um controle do processo de comunicação, tal como definido por Authier-Revuz (2004). É uma marcação de heterogeneidade explícita de concordância com a voz do outro, seu uso indica conformidade do eu com o já-dito que é referenciado. Nesse caso, aquele que escreve evidencia a afirmação que faz com a voz do outro; não há um enunciado próprio do texto ou uma articulação do dizer produzido mediante o uso de discurso indireto ou mesmo de comentários do autor.

Nota-se que, para construir um discurso de adequação ou concordância com o outro, o aluno desenvolve uma escrita na qual inclui seu próprio discurso apenas para concordar com o discurso ao qual nos remete por meio da citação (linhas 03 a 13) ou para adequar-se a ele. Essa citação 
faz alusão aos conceitos de código e transmissão e é empregada numa tentativa de explicar o porquê de se utilizar a teoria da Análise do Discurso como base de fundamentação da análise do corpus. No entanto, o autor da monografia não desenvolve ou explica a diferença entre os conceitos de "transmissão de informação" e "processo de significação". Além disso, ele não faz comentários ou teorizações; a remissão e a apresentação dos conceitos de transmissão e código são realizadas pela autora citada. Não se realiza, por conseguinte, a mobilização do dizer de quem escreve e nem sua articulação com o discurso do outro que é citado.

Na linha 14, há uma marcação do mesmo autor da citação recuada, apresentada após a locução "Como já discutimos" para fazer remissão à "noção de leitura" do autor marcado. Não temos desenvolvimento do conceito de leitura nem a discussão a que se fez alusão. Observamos uma marcação nova do mesmo autor para apresentar outro conceito - o de "material simbólico" e remeter à teoria utilizada como fundamentação teórica.

Na sequência do texto, na linha 16, há uma marcação em itálico de uma concepção do autor citado, que serve para introduzir, na linha 17, a ideia de efeitos de sentido sem conceituar ou explicá-la. É como se fosse pressuposto que todos sabem o que o texto e a autora que é citada em diversos momentos querem passar ao falar sobre efeito de sentidos.

Na linha 18, utiliza-se a locução "em relação" como forma de remeter a conceitos que, supostamente, todos os leitores conhecem, pois não é desenvolvida uma reflexão sobre as "discussões de Orlandi". 0 único referencial são as citações diretas apresentadas no decorrer do texto que consideramos como mais uma marcação do discurso de outro autor, como formas de apresentar os conceitos do dizer referenciado.

Nas linhas 19 e 20, o autor do texto tenta estabelecer uma relação entre um conceito teórico e o corpus que se propôs a analisar. Porém, não há desenvolvimento do conceito ou articulação com o corpus. Pressupõese que todos os leitores compreenderão o que se quer dizer com "relato como um espaço simbólico do discurso da Dança do Chorado", mas não há explicação sobre o que é "espaço simbólico" ou mesmo sobre o que é o "discurso da Dança do Chorado".

Ao final, nas linhas 21 e 22, uma nova marcação aparece. 0 uso do conectivo "De acordo", seguido do nome do autor, novamente citado, sinaliza uma tentativa de concordância e conformidade. Na sequência, outros conceitos são apresentados sem explicação ou conceituação, como, 
por exemplo, "imaginário de unidade e de autoria" e "discurso imaginário da função-autor". Esses conceitos são desenvolvidos em seguida, mas por meio de uma nova citação direta da mesma autora já citada por diversas vezes.

A análise parece repetitiva em consequência da repetição maciça de marcações de uma autora em citações diretas ou em tentativas de paráfrases, como ocorre entre as linhas 14 e 22, que revelam um modo de escrita organizado de forma a dar voz para o autor citado.

Da linha 23 a 28, há, novamente, uma citação direta recuada, que apresenta o conceito teórico citado na linha 22 - "função-autor" -, que não foi conceituado por aquele que escreve, mas comentado a partir de paráfrases. A escrita apresentada no texto que analisamos, demonstra que aquele que escreve apresenta e cita diversos conceitos, dando como referência discursos de uma autora reconhecida e consolidada para conceituar e explicar o que menciona. Não vemos, porém, a articulação de comentários com os discursos do autor que é citado ou com o corpus da pesquisa do graduando. Tal característica é perceptível no texto desenvolvido entre as linhas 29 e 33, quando aquele que escreve relaciona os conceitos apresentados pelas citações do outro com o "depoimento sobre o Chorado", que é apresentado como corpus da investigação.

0 texto apresenta, portanto, diversos conceitos, mas não os explica ou os articula com o que se propõe a analisar. Podemos utilizar, como exemplos, os casos de "imaginário de textualidade", na linha 29, "gesto de interpretação" e "materialização do simbólico", na linha 30, e "imaginário de unidade dos sentidos", na linha 31. Esses conceitos teóricos não são apresentados, explicados e conceituados, e apenas sua apresentação, juntamente com as citações, não permite entender os conceitos nem dar conta do objetivo proposto no trabalho.

Outro fato a ser considerado é que a referência que o aluno faz a Orlandi (2002) retoma conceitos que não são especificamente dessa autora. São, sim, termos consolidados na comunidade linguística, como "material simbólico", "significação", "transmissão de informação", entre outros, cuja origem o aluno atribui à autora citada. Podemos entender esse equívoco como uma dificuldade própria desse momento de escrita, pois é um período de aprendizagem do graduando, e a monografia pode ser considerada como a primeira experiência de escrita acadêmica que resulta de uma investigação. 
Esse tipo de produção que desenvolve um efeito de promoção e em que o autor se utiliza da alegação da dificuldade de escrever como forma de justificar as falhas de escrita é um exemplo de trabalho, muitas vezes, reconhecido na universidade. Além de se aceitar essa produção como um trabalho inicial de monografia, esse modo de escrita que promove o autor é aceito como próprio à pesquisa, criando a ilusão de que contribui com a produção científica na universidade, o que também questionamos, considerando a quantidade e a popularização de trabalhos com essas características, os quais ganham a cada dia mais espaço e incentivo.

\section{Os efeitos de sentido da escrita de monografias: a promoção de conceitos teóricos}

0 modo de escrita que analisaremos, no Excerto 02, aproxima-se do que vimos no anterior, porém, temos outro tipo de efeito de sentido construído. A diferença está na forma do sentido produzido. 0 texto tem como característica o encadeamento de vários conceitos teóricos que não são mobilizados e operacionalizados em análises. Os termos de uma determinada perspectiva teórica não são necessariamente bem definidos, explicados ou desenvolvidos, revelando um efeito de sentido pelo qual o texto os promove e os oferece como instrumento de análise do corpus do trabalho. Nesse caso, temos um exemplo de efeito de sentido de promoção de conceitos teóricos.

\section{Excerto 02 - Aluno B}

\footnotetext{
01 Alguns consideram o já-dito enquanto um fechamento dos sentidos, pois este, em 02 certa medida, delimita, imobiliza. Entretanto, podemos pensar, com Orlandi (2009, p.9) 03 "[...] que aquilo que se diz, uma vez dito, vira coisa no mundo: ganha espessura, faz 04 história". Desse modo, apontar para o estabelecimento do não-estabelecido e 05 questionar a consciência hegemônica (o sentimento) dessas distinções no homem de 06 linguagem, fornece fôlego para a nossa concepção de trabalho, qual seja, a língua 07 pensada por uma teoria materialista de linguagem. Também, a questão da memória 08 se mostra sensível quando, sobretudo, "[...] ela opera sob a forma da evidência dos 09 sentidos, aparecendo [...] nas suas falhas" (PAYER, 2009, p.42).
}

Na linha 01, aparece o pronome indefinido "alguns", uma palavra não anafórica, ou seja, sem relação semântica com outro termo ou sentido referente. Como afirma Neves (2000, p.534), são "considerados indefinidos de identidade os pronomes cuja referência não pode ser identificada". A 
utilização desse pronome funciona, então, como um recurso linguístico que marca a indefinição da referência que o aluno faz aos autores que apresentam o conceito linguístico de "já-dito" na linha 01 e marca, de certa maneira, um distanciamento do que é citado naquele momento. Por sua vez, a marcação por meio do uso de "entretanto" funciona como marca de adequação e adesão ao que é dito a seguir e de negação à primeira referência realizada, como podemos confirmar na linha 02 . 0 uso do conector acrescenta, portanto, uma marca de adversidade em relação ao trecho iniciado pelo pronome indefinido. 0 aluno, assim, recusa um dizer alheio e indefinido para filiar-se a outro, o da autora que aparece predominantemente no seu texto.

0 uso do conector indefinido para marcar uma contrariedade com um autor não referenciado, evidência o discurso de outro autor utilizado como fundamentação teórica do trabalho. Isso, em conjunto com os outros usos aqui analisados, provoca um efeito de sentido durante a leitura. 0 que compreendemos como uma forma de promoção de um conceito.

Nesse caso, a forma de organização das marcas de outros discursos na produção escrita constrói entre as palavras um jogo que nega certos discursos ou os invalida, como o que vemos na linha 01 com o uso do conectivo "alguns". 0 texto desqualifica ou recusa o conceito de já-dito como um "fechamento de sentidos". Esse jogo de palavras contraria a definição corriqueira do termo e reforça a aproximação com a conceituação apresentada pela voz de Orlandi, que, além de marcada, é considerada, na escrita do aluno, como a voz correta e verdadeira, que deve ser seguida em oposição àquelas apresentadas indefinidamente na linha 01. Ao mesmo tempo, a produção daquele que escreve não se desenvolve, ela apenas consolida e reproduz outros discursos já reconhecidos.

Esse efeito de promoção é caracterizado pelo destaque dado aos conceitos de uma determinada voz, no caso, a de Orlandi. Tal modo de escrita cria um efeito de sentido que entendemos como forma de promover o outro. É caracterizado pelas marcações da voz de outros autores por meio de citações recuadas, paráfrases e/ou reformulações de um discurso conhecido. Essa estrutura de escrita, involuntariamente, passa a ideia de que o discurso do outro tem prestígio especial, uma prática que pode ser observada no "jogo" da academia, ou seja, é uma situação comum na universidade.

Temos assim a criação da imagem de que a reprodução de um discurso ao qual estamos filiados e com o qual estabelecemos ligação e 
aproximação, seja por ser de um autor reconhecido, seja para sermos respeitados pelos pares que utilizam a mesma teoria ou conceito como fundamentação é aceita como produção científica, em razão do efeito de sentido de promoção de um autor respeitado e reconhecido e não pela relevância da investigação realizada.

Isso contraria, em certa medida, alguns critérios necessários para reconhecer um texto acadêmico enquanto produção científica, como a construção de valor científico (grau de relevância para a ciência) através da articulação entre conceitos teóricos e análise de dados. Essa articulação poderia auxiliar o jovem pesquisador a responder os questionamentos que o levaram a propor determinada investigação.

Não estamos problematizando vontades ou intenções, mas refletindo sobre a possibilidade de que as diferentes formas de escrita estejam ligadas às maneiras como realizamos a articulação do discurso de outros autores com aquele que estamos produzindo. Além de constitutiva, a alteridade incita-nos a estabelecer relações com os discursos já realizados, contudo, conforme estruturamos um dizer, podemos construir efeitos de sentido que nem sempre condizem com o que estamos propondo, mas que não impedem que o trabalho se constitua como produção.

Ao mencionarmos ligação, aproximação e filiação de um pesquisador a uma teoria, referimo-nos ao conhecimento que aquele que escreve tem sobre autores ou teorias para desenvolver seus trabalhos e atividades durante a formação acadêmica. Para realizar uma produção escrita, desenvolve-se um vínculo com um ou mais pressupostos teóricos que, em sua maioria, são instituídos por um autor reconhecido que já tenha contribuído com a produção científica. São esses autores que estudamos durante a formação que utilizamos em citações com o objetivo de confirmar nossos dizeres e garantir o caráter científico das pesquisas que realizamos.

Entretanto, dependendo da forma de se relacionar com uma teoria ou com um determinado autor - isto é, como se utiliza os conceitos e discursos de outros autores -, da experiência de orientação vivenciada e de diversas outras questões, os universitários desenvolvem diferentes formas de produção escrita, e uma delas pode contribuir para que as investigações de iniciação científica, como de monografias, estruturem-se por meio da repetição e de citações soltas de autores renomados sem articulação com a proposta inicial do trabalho. Trata-se de escrever um texto 
cuja teoria não funciona, predominantemente, como subsídio do trabalho. Ao contrário, a produção escrita é que subsidia a teoria, colocando-a em evidência, exaltando-a, o que constrói um sentido de que o texto promove quem é citado.

Algo parecido pode ser percebido no Excerto 2, quando, na referência a Orlandi, na linha 02 , o aluno faz uso da locução verbal "podemos pensar" em conjunto com a preposição "com". A marcação evidencia que os pensamentos dele sobre as teorias que apresenta não são apenas mediados pela voz que cita, mas são literalmente do outro. É interessante observar essa ocorrência, lembrando que Authier-Revuz (2004), ao afirmar que a organização do discurso se dá a partir do outro, não exclui dessa relação o eu. A utilização da locução verbal "podemos pensar" como conectivo para marcar a voz do outro parece demonstrar que o texto produzido é uma forma de reproduzir a maneira de pensar do autor citado e que não temos uma reflexão daquele que escreve.

Ainda analisando o dado anterior, notamos que o uso da conjunção conclusiva "desse modo", na linha 04, estabelece uma retomada da citação de Orlandi nas linhas 02 a 04. Tal uso é uma modalização em discurso segundo uma maneira de quem escreve concordar com o autor que foi citado antes do uso do conectivo em questão, o que pode ser considerado inicialmente como um argumento de autoridade, uma forma de confirmar um discurso através do dizer de um autor já reconhecido na academia.

As formas de marcação do discurso de outros autores na escrita dos textos que analisamos controlam o discurso do aluno. Conforme percebemos, em grande parte, evidenciam a voz do outro, do autor reconhecido. 0 texto faz remissão a conceitos que não são empregados no trabalho, não funcionam como categorias de análise e não lhe dão sustentação teórica, desenvolvendo-se um sentido de que o texto produzido é apenas um mecanismo de demarcação da filiação teórica de quem escreve a uma autora renomada e reconhecida como autoridade sobre a teoria utilizada.

Na linha 07 , o conectivo "também", um advérbio com valor de adição e ênfase, é utilizado para destacar algo que será incluído no texto. Nesse caso, inclui-se o conceito de memória antes da referência ao discurso de outro autor. Temos a menção de um novo termo da teoria da Análise do Discurso, "memória", que novamente não é explicado ou descrito por quem escreve; sua conceituação é desenvolvida depois, a partir de uma nova citação do discurso de outro autor. 
Num segundo momento, esse mesmo "também" funciona como um recurso de antecipação da citação de Payer. É uma maneira diferente de marcar a voz do outro. Dessa vez, o conectivo apresenta a voz citada nas linhas 08 e 09 em uma ilha textual que, segundo Authier-Revuz (p.16, 2004), é uma das formas de marcação da heterogeneidade discursiva, caracterizada pela transcrição.

A utilização do conectivo "sobretudo", na linha 08, confirma a tentativa de se estabelecer relação com o termo que o conectivo "também" introduziu e, assim, remeter à voz do outro que é citada. Observamos que esses conectores são utilizados como mediadores da citação e como uma marcação do discurso do outro que é citado, como constatamos com a marcação do dizer de Payer nas linhas 08 e 09, apresentado pelos conectores "também" e "sobretudo", que antecipam e demonstram uma aproximação com a citação do autor.

Além das linhas 08 e 09, encontramos ilhas textuais nas linhas 03 e 04. Elas são formas de modalização autonímica, ou seja, de marcação do discurso do outro dentro do próprio discurso.

A conotação autonímica pode ser representada pela apresentação de discursos entre aspas, em itálico etc. Essas formas de conotação funcionam como um argumento de autoridade na escrita daquele que redige o texto. Trata-se de uma maneira de argumentar que consiste em utilizar o discurso de um autor reconhecido pela academia para confirmar o que estamos dizendo, como forma de garantir a veracidade e obter respaldo científico para o que escrevemos.

No caso do Excerto 2, vemos que a escrita desenvolvida aponta para um encadeamento de autores que confirmam o dizer daquele que foi marcado, mas não demonstram uma posição enunciativa daquele que escreve nem apresentam uma citação que confirme um dizer dele. A produção escrita é caracterizada pelas vozes dos outros autores citados, como Payer nas linhas 08 e 09, que complementam o conceito apresentado por Orlandi nas linhas 02 e 04 .

A escrita desenvolvida com essas marcações que produzem um efeito de promoção dos conceitos teóricos também é objeto de reflexão sobre o silenciamento da voz de quem escreve. A produção em questão, ao se utilizar das citações de diferentes autores e desenvolver o sentido de promoção, sem articular os pressupostos teóricos com uma análise de dados, apaga a posição de enunciador do aluno, que se reduz ao estatuto 
de suporte, de porta-voz do dizer de outro autor, não realizando o trabalho que se propôs a fazer, mas, mesmo assim, tendo sua produção reconhecida pela comunidade científica.

Como discutimos o encadeamento de conceitos teóricos sem explicação, apresentamos, nas linhas abaixo, uma síntese dos dados, que confirma nossa hipótese, considerando que o excerto já não está muito próximo.

01: conceito de "já-dito"

04: de "não-estabelecido"

05: de "consciência hegemônica"

07: de "teoria materialista de linguagem" e "memória"

A análise do Excerto 2 revelou a presença de marcas, conectores e citações, que referenciam outras vozes no texto do locutor através de discurso relatado indireto. Para Authier-Revuz (2004, p.12), essa demonstração de heterogeneidade explícita do discurso é caracterizada pelo comportamento do autor como tradutor, pois "fazendo uso de suas próprias palavras, ele [o aluno] remete a outro como fonte do 'sentido' dos propósitos que ele relata”.

Para a metodologia de iniciação científica, as marcações da voz do outro funcionam, nas produções escritas e investigações, como argumentos de autoridade, que são utilizados a fim de confirmar e sustentar aquilo que se defende e analisa, sem com isso construir uma ideia de que o texto exalta e promove autores da teoria da Análise do Discurso. Contudo, no caso analisado, vemos uma escrita que demarca as vozes do outro e reproduz os conceitos teóricos de autores consolidados, originando o efeito de promoção do autor citado ou do conceito que é, por diversas vezes, referido.

\section{Considerações finais}

Iniciamos esta seção retomando a pergunta de pesquisa que desencadeou nossa proposta de investigação: Quais os efeitos de sentido produzidos a partir do modo de utilização da voz do outro na escrita de textos acadêmicos?

As análises realizadas nos confirmam que o uso de fundamentação teórica nos trabalhos de investigação é necessário para a produção de trabalhos acadêmicos como monografias. 0 uso do discurso do outro é uma prática que garante a credibilidade de produções escritas, funcionando como argumentação e dando sustentação do dizer daquele que escreve. 
Ao cumprir nossos objetivos de analisar as marcações do outro (autor, conceito teórico, área de conhecimento); e observar os efeitos de sentido produzidos por essa marcação, foi possível verificar a existência de diferentes modos de um jovem pesquisador se relacionar com uma teoria.

Com isso, observamos que uma produção escrita pode evidenciar o desenvolvimento de efeitos de sentidos no qual o texto perde a funcionalidade de propor algo novo e produtivo para o universo acadêmico para promover o dizer utilizado como referência, seja na forma de um conceito teórico ou na marcação de um autor reconhecido.

Ao analisar os efeitos de sentido desenvolvidos a partir da forma de utilização do outro na produção escrita, verificamos que a produção de determinados sentidos, como esse da promoção, pode garantir a aceitação e a aprovação do trabalho acadêmico pelos pares de quem escreve, bem como legitimar sua publicação em revistas e boas avaliações em bancas de monografias. Isso independentemente do trabalho desenvolver uma articulação e mobilização da fundamentação teórica com uma análise de dados.

A análise das monografias nos permitiu perceber a construção de uma produção escrita que não realiza uma análise do corpus que apresenta como dado, mas sim o desenvolvimento de uma escrita a partir de repetições da teoria de outro autor. Ressaltamos que nosso propósito foi analisar esse uso para refletir sobre os modos de escrita que são aceitos e entendidos como produções de trabalhos acadêmicos e não para acusar ou culpabilizar aquele que escreve desse modo.

Entendemos que quem escreve um texto é responsável pelo seu dizer e que, em situações como as que analisamos, produzem-se certos efeitos que geram o sentido de que a responsabilidade do que é dito no texto é do autor que é citado e não daquele que escreve, considerando qual voz realiza a apresentação dos conceitos e quantas vezes um mesmo autor é marcado. Observamos que esse modo de escrita repetidora dá origem a uma ideia de hierarquia de conceitos teóricos e cria a imagem de que o texto acadêmico funciona como meio de transmissão e repetição do já-dito.

Por fim, não desconsideramos a presença do outro como parte constitutiva do dizer. Entendemos que há diversos modos de utilizar ou dar voz ao dizer do outro. Assim, podemos utilizar a voz do outro como argumento ou construir um modo de escrita baseado na repetição. Considerando, nesse último caso, a possibilidade de uma inversão 
do papel de quem escreve com a referência teórica utilizada, ou seja, o discurso daquele que escreve desenvolve a função de evidenciar a participação do outro que é citado.

\section{Referências}

AUTHIER-REVUZ, J. Entre a transparência e a opacidade: um estudo enunciativo do sentido. Tradução de Leci Borges Barbisan e Valdir do Nascimento Flores. Porto Alegre: EDIPUCRS, 2004.

CORACINI, M. J. R. F. Discurso e escrit(ur)a: entre a necessidade e a (im)possibilidade de ensinar. In: CORACINI, Maria José Rodrigues Faria; ECKERT-HOFF, Beatriz. (Org.). Escrit(ur)a de si e alteridade no espaço papel-tela (formação de professores, línguas materna e estrangeira). Campinas: Mercado de Letras, 2010, p.17-50.

FERREIRA, A. Aurélio século XXI. 3ed. Rio de Janeiro: Nova Fronteira, 1999, 2128p.

FUCHS, C. A paráfrase linguística: equivalência, sinonímia ou reformulação? Caderno de Estudos Linguísticos. Tradução de João Wanderlei Geraldi. Campinas: n.8, 1985,p.129-134.

KUHN, T. S. A estrutura das revoluções científicas. Tradução de Beatriz Vianna Boeira e Nelson Boeira. 10ed. São Paulo: Perspectiva, 2011.

NEVES, M. H. M. Gramática de usos do português. São Paulo: Unesp, 2000.

POSSENTI, S. Indícios de autoria. In: PERSPECTIVA - revista do centro de ciências da educação. Florianópolis: Ed da UFSC, 2002.

ROSSI-LANDI, F. A linguagem como trabalho e como mercado: uma teoria da produção e da alienação linguísticas. Tradução de Aurora Fornoni Bernardini. São Paulo: Difel, 1985.

POSSENTI, S. Sobre as noções de sentido e de efeito de sentido. Cadernos da F.F.C.: Análise do Discurso, Marília, v.6, n.2, p.3-11, 1997. 